\title{
A Comparative Study of Different Proportions of Superdisintegrants: Formulation and Evaluation of Orally Disintegrating Tablets of Salbutamol Sulphate
}

\author{
Salbutamol Sülfatın Oral Dağılan Tabletlerinin Formülasyonu ve \\ Değerlendirilmesi: Süper Dağıtıcıların Farklı Oranlarının Karşılaştırmalı
} Çalışması

\author{
Ajay KUMAR, Vikas Anand SAHARAN* \\ Department of Pharmaceutics, School of Pharmaceutical Sciences, Sardar Bhagwan Singh Post Graduate Institute of Biomedical Sciences and Research, \\ Balawala, Dehradun 248161, Uttarakhand, India
}

\begin{abstract}
Objectives: Superdisintegrants play important role in disintegration of orally disintegrating tablets (ODTs). Action of three different superdisintegrants, viz. croscarmellose sodium, sodium starch glycolate and Indion 414, were studied individually or in their binary combinations for their fast disintegrant action in ODTs of salbutamol sulphate prepared by direct compression.

Materials and Methods: ODTs were prepared in three different superdisintegrant combinations A, B and C. In each combination, five formulations were prepared with superdisintegrants in ratios 10:90, 25:75, 50:50, 75:25, and 90:10. Three ODT formulations were prepared with single superdisintegrant and two ODT batches were prepared from marketed ODT excipient blends, viz. Prosolv-ODT and F-Melt. Prepared ODT formulations were evaluated and compared for weight variation, hardness, friability, wetting time, disintegration and drug release.

Results: All ODTs disintegrated quickly in 32 s or less. ODT formulation F3, containing croscarmellose sodium and sodium starch glycolate, disintegrated very quickly in $19.28 \pm 3.11 \mathrm{~s}$. Results of F3 were compared with the batches (F19 and F20) containing marketed coprocessed excipients and found in good agreement for various evaluation parameters. Formulation F20 was hygroscopic, while F3 did not suffer this disadvantage.

Conclusion: Thus, we may conclude that superdisintegrants in combinations may offer additive and/or synergistic disintegration possible due to their different mechanism
\end{abstract}

Key words: Wetting, disintegration, dissolution, croscarmellose sodium, sodium starch glycolate, Indion 414

ÖZ

Amaç: Farklı üç süper dağııcının, ki bunlar; kroskarmeloz sodyum, sodyum nişasta glikolat ve Indion 414, doğrudan basım ile hazırlanan salbutamol sülfat oral dağılan tabletlerinde (ODT) hızlı dağıtma etkisi için ayrı ayrı veya ikili kombinasyonlarında çalışıldı.

Gereç ve Yöntemler: ODT'ler farklı üç süper dağıtıcı kombinasyonunda; A, B ve C, hazırlandı. Herbir kombinasyonda süperdağıtıcıların 10:90, 25:75, 50:50, 75:25 ve 90:10 oranlarında beș formülasyon hazırlandı. Üç ODT formülasyonu tek süper dağıtıcı ile ve iki ODT serisi piyasadaki ODT eksipiyanları ile ki bunlar, Prosolv-ODT ve F-Melt, hazırlandı. Hazırlanan ODT formülasyonları ağırlık sapması, sertlik, friabilite, ıslanma zamanı, dağılma ve etken madde salımı için değerlendirildi ve karşılaştırıldı.

Bulgular: Tüm ODT'ler 32s veya daha kısa sürede dağıldı. Croscarmellose sodyum, sodyum nişasta glikolat içeren F3 ODT formülasyonu $19.28 \pm 3.11$ s de çok hızı dağıldı. F3'ün sonuçları piyasadaki koproses eksipiyanları içeren serilerle (F19 ve F20) karşılaştıııldı ve çeșitli değerlendirme parametreleri için iyi bir uyum olduğu bulundu. F20 formülasyonu higroskopik iken F3 formülasyonunda bu dezavantaj yoktu.

Sonuç: Böylece, kombinasyondaki süper dağııcıların farklı mekanizmalarına bağlı olarak olası ilave ve/veya sinerjik dağılmayı sağlayabileceği sonucuna varabiliriz.

Anahtar kelimeler: Islanma, dağılma, çözünme, kroskarmeloz sodyum, sodyum nişasta glikolat, Indion 414

*Correspondence: E-mail: vikas.pharmaceutics@gmail.com, Phone: +91-8439820796

Received: 18.06.2016, Accepted: 14.07.2016

๑Turk J Pharm Sci, Published by Galenos Publishing House. 


\section{INTRODUCTION}

Novel drug delivery system aims to enhance safety and efficacy of drug molecule by formulating a convenient dosage form for administration and to achieve better patient compliance. One such approach is oral disintegrating tablets (ODT) which are those solid dosage forms when put on tongue, disintegrate or dissolve instantaneously, releasing the drug, within a few seconds without the need of water. ODT is also known as fast melting, fast dispersing, rapid dissolve, rapid melt and/ or quick disintegrating tablet. ODT can be administered easily to dysphagic adults, pediatrics, geriatrics, mentally ill, uncooperative and nauseated patients. 'Disorder of dysphagia is associated with many medical conditions including stroke, Parkinson's disease, AIDS, thyroidectomy, head and neck radiation therapy and other neurological disorders including cerebral palsy. One study showed that $26 \%$ out of 1576 patients experienced difficulty in swallowing tablets due to their large size, followed by their surface, shape and taste..$^{2,3}$ The centre for drug evaluation and research, US Food and Drug Administration defined ODT as "A solid dosage form containing medicinal substances, which disintegrates rapidly, usually within a matter of seconds, when placed upon the tongue". ${ }^{4}$ The disintegration time for ODTs varies from a few second to more than a min depending upon the formulation and size of the tablet. ODT also offer rapid disintegration followed by fast dissolution and absorption, which may produce rapid onset of action. Increase in bioavailability is expected for drugs which are absorbed from the mouth pharynx and oesophagus as the saliva passes down into the stomach. Convenience of administration, accurate dosing when compared to liquids, liquid medication in the form of solid form, no need of water to swallow and good mouthfeel are some other salient features of ODTs. ${ }^{5}$

Salbutamol (albuterol) is a $\beta 2$ adrenergic agonist, it cause bronchodilation through $\beta 2$ receptor stimulation via increased cyclic adenosine monophosphatedan formation in bronchial muscle cell which cause relaxation. Its action start within 1520 min and lasts for 3-4 hour. ${ }^{6}$ It is therefore used to abort and terminate attacks of asthma. Muscle tremors is the dose related side effect of this drug. Asthma is common problem to large number of people and asthmatic attack to a patient needs a quick onset of action for instant relief, ODT of salbutamol sulphate will help to achieve a quick action by faster disintegration and/ or dissolution than conventional tablet. ODTs of salubutamol sulphate have been reported in several research reports..$^{7-12}$ In one study Plantago ovata husk and powder was used as disintegrant in preparing Salbutamol sulphate ODTs. ${ }^{7}$ Plantago ovata husk and powder was superior to croscarmellose sodium (CCS) and sodium starch glycoate in disintegration action. CCS, alginic acid, sodium starch glycolate (SSG), modified guar gum and modified agar were used as disintegrants in preparing ODTs of Salbutamol sulphate. ${ }^{8}$ Quantities of PVP K30, sodium starch glycoate and microcrystalline cellulose (MCC) were optimized to achieve faster disintegration and adequate mechanical strengths. ${ }^{9}$ Both, intragranular and extragranular incoroporation of crocarmellose XL-10 in formulations were found effective and superior disintegrant action when compared with CCS, starch glycolate and low substituted hydroxyl propyl cellulose (L-HPC) in preparing salbutamol sulphate ODTs by direct compression and wet granulation." In another attempt salbutamol sulphate ODTs were prepared with combination of superdisintegrant (crospovidone) and subliming agents (camphor, menthol, thymol and ammonium bicarbonate) to achieve quick disintegration with optimum mechanical strength.12 Primojel, L-HPC, Kollidon $\mathrm{CL}$ and Primojel were used individually in achieving fast disintegration of ODTs of salbutamol sulphate. ${ }^{10}$

The use of superdisintegrants in ODTs has become popular for various reasons. For tablet containing sparingly water soluble drugs, the start of dissolution is often delayed by poor wettability of tablet or slow liquid penetration into tablet matrix this causes increase in disintegration time and retards the drug release. This can be overcome by addition of superdisintegrants.13 The mechanism of action of superdisintegrants may be by wicking, swelling, which is found to effect primarily for tablet disintegrants, while other mechanisms, such as deformation recovery, particles repulsion theory, heat of wetting and evolution of a gas etc., may play a role in particulate cases of tablet disintegration.

SSG is the sodium salt of a carboxymethyl ether of starch or of a cross linked carboxymethyl ether of starch. It is effective at a concentration of $2-8 \%$. SSG swells $7-12$ folds in less than 30 seconds and it swells in three dimensions and high level serve as sustain release matrix. It can take up more than 20 times its weight in water and the resulting high swelling capacity combined with rapid uptake of water accounts for its high disintegration rate and efficiency.

CCS is the sodium salt of a cross linked, partly $O$ (carboxymethylated) cellulose. CCS swells 4-8 folds in less than 10 seconds and the mechanism of disintegrant action is swelling and wicking both. Its swelling is in two dimensions and it is used as a starch free disintegrant for direct compression and granulation. CCS and SSG, both are sodium salts, anionic and their polymer backbones are composed mostly of glucose units. ODT tablets containing CCS and SSG disintegrate almost instantaneously when they will come in contact with even slight amount of saliva or water. ${ }^{14}$

Indion 414 is a weak acid cation exchange resin based on crosslinked polyacrylic acid (Indion 414 brochure). ${ }^{15}$ It is supplied as potassium salt for use in pharmaceutical formulations as disintegrant and taste masking agent. A concentration of $0.5-2 \%$ is sufficient as disintegrant in conventional tablets. However, in ODTs, amounts higher than this may be added to achieve faster disintegration. Additionally it does not have an adhesive tendency and is insoluble in water and common solvents. Indion 414 provides good mechanical strength to the tablet which facilitate easy transportation, and packing. It swells to about $700 \%$ when it comes in contact with water or gastrointestinal fluid causing rapid disintegration without formation of lumps. In one research report, swelling index of 800 was estimated for Indion 414 and 750 for SSG and 700 for CCS in simulated saliva. ${ }^{15}$

The aim of present study is to formulate salbutamol sulphate ODTs using three different superdisintegrants, viz. SSG, CCS and 
Indion 414, and their binary combinations to find out the effect on various evaluation parameters of prepared ODTs. Marketed ODT blends Prosolv-ODT and F-melt were also used to prepare salbutamol sulphate ODTs and results were compared to ODTs containing various combinations of superdisintegatnts.

\section{MATERIALS AND METHODS}

\section{Materials}

Salbutamol sulphate was purchased from Yarrow Chem. Products, Mumbai. CCS was received as gift from JRS Pharma, Germany. SSG and MCC were purchased from Signet Chem. Corporation, Mumbai. Indion 414 was received as a gift from Ion Exchange (India) Ltd, Gujarat. Mannitol was ex gratis sample from Service Techniques Et Laboratories, Lestrem, France. Magnesium sterate, talc, saccharin sodium was purchased from Loba Chemie Pvt Ltd. Mumbai. F-melt type C and Prosolv ODT were received as ex gratis samples from Fuji Chemical Industry Co. Ltd., Tokyo and JRS Pharma, Germany. All other chemicals and reagents used were of analytical grade.

\section{Methods}

\section{ODT formulations}

ODTs of salbutamol sulphate were prepared by direct compression. CCS, SSG and Indion 414 were used as superdisintegrants. Formulations were prepared in three different combinations $A, B$ and $C$. In each combination, two superdisintegrants were used and five different formulations were prepared. Total amount of superdisintegrants in the formulation was fixed as $25 \mathrm{mg}$ in the tablet of total weighing $200 \mathrm{mg}(12.5 \% \mathrm{w} / \mathrm{w}$ superdisintegrant of total weight of tablet). Proportion of both superdisintegrants were varied in a sequential pattern, 10:90, 25:75, 50:50, 75:25 and 90:10, to achieve five different formulations of one combination. Compositions of various tablet formulations are provided in the Table 1. Batches F16, F17, F18 were prepared with individual superdisintegrant SSG/CCS/Indion 414 respectively at $12.5 \%$ w/w. Batch F19 and F20 were prepared with marketed ODT blends, Prosolv-ODT and F-Melt, respectively.

MCC was used as a filler in same amount i.e. $50 \mathrm{mg}(25 \% \mathrm{w} / \mathrm{w}$ of total tablet weight) in all the tablets. Mannitol was used as filler and diluent of the tablet in same amount i.e. $105 \mathrm{mg}(52.5 \%$ of total tablet weight-200 mg) in all tablet formulations. Talc, 4 $\mathrm{mg}$, was used as glidant and magnesium stearate, $4 \mathrm{mg}$, was used as lubricant. Saccharin sodium, $8 \mathrm{mg}$, was used as a sweetening agent. Drug and excipient except talc were mixed geometrically in a mortar pestle and with the help of pestle and spatula for around half an hour then finally talc was added to the powder blend and mixed in a polybag.

\section{Evaluation of powder blends}

Powder blends have been evaluated for bulk density, tapped density and angle of respose Compressibility Index and Hauser's ratio were calculated from bulk and tapped density of the powder blends.

\section{Bulk density}

Apparent bulk density $(\mathrm{g} / \mathrm{mL}$ ) was determined by pouring bulk powder into a graduated cylinder and measuring the volume and weight. Bulk density $\left(\rho_{b}\right)$ was calculated by the following formula.

$\rho_{b}=M / V_{b}$, where, $M=$ mass of the powder and $V_{b}=$ bulk volume of the powder

\section{Tapped density}

Apparent bulk density $(\mathrm{g} / \mathrm{mL}$ ) was determined by pouring bulk powder into a graduated cylinder and measuring the initial volume and weight. Then the cylinder was allowed to fall under its own weight onto a hard surface from a constant height, the tapping was continued until no further change in volume was noted. Tapped density $\left(\rho_{\mathrm{t}}\right)$ can be calculated by the following formula.

$\rho_{t}=M / V_{t}$, where, $M=$ mass of the powder and $V_{t}=$ final volume of the tapped powder

\section{Carr's index}

It was calculated according to the following equation.

Carr's index $(\%)=\left[\left(\rho_{t}-\rho_{b}\right) / \rho_{t}\right] \times 100$

\section{Hausner's ratio}

It was calculated by the following formula.

Hausner Ratio $=\rho_{\mathrm{b}} / \rho_{\mathrm{t}}$

\section{Angle of repose}

The powder was allowed to flow through the funnel fixed on a tripod stand at definite height. The angle of repose is then calculated by measuring the height $(h)$ and radius $(r)$ of the heap of powder, formed. Angle of repose was calculated by the formula $\theta=\tan ^{-1}(h / r)$.

\section{Preparation and evaluation of tablets}

Bioconvex ODTs were prepared in direct compression of the powder blends in a rotary tablet machine CMD3-16 (Cadmach, Ahmedabad) operated manually with one set of punch only. The compositions of the prepared ODTs are given in Table 1.

\section{Weight variation}

Tablets $(n=20)$ were selected at random and average weight was calculated. Percentage deviation from the average was calculated.

\section{Hardness}

Hardness of the tablets was determined as force required to fracture the tablet when placed diametrically in a monsanto hardness tester. The tester consists of a barrel containing a compressible spring held between two plungers. The lower plunger is placed in contact with the tablet and a zero reading was observed. The upper plunger was forced against a spring by turning a thread bolt until the tablet fractures. As the spring was compressed, a pointer rides along a gauge in the barrel to indicate the force, which was a measure of hardness. 
Table 1. Composition of various salbutamol sulphate ODTs

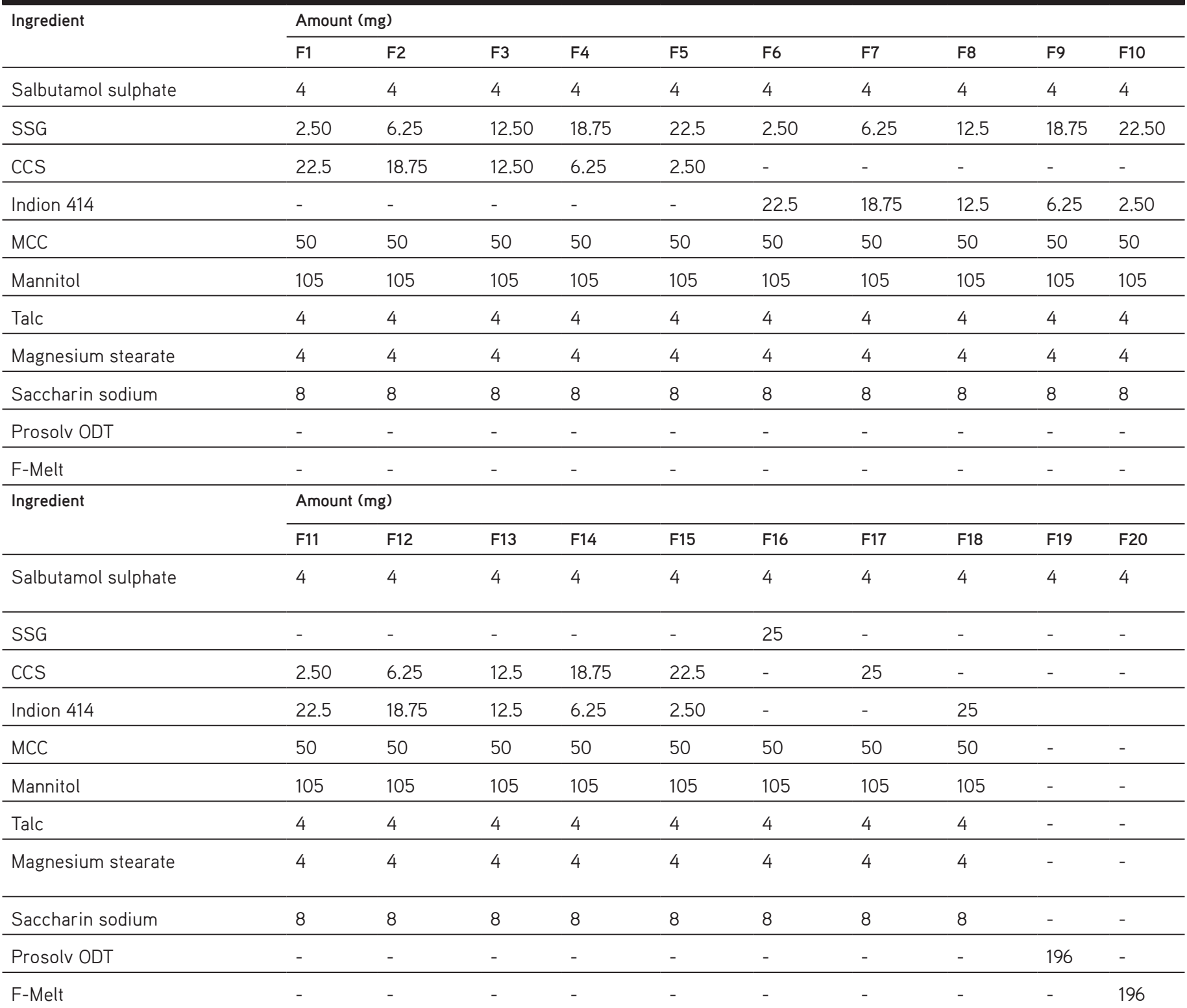

ODTs: Oral disintegrating tablets, SSG: Sodium starch glycolate, CCS: Croscarmellose sodium, MCC: Microcrystalline cellulose

Wetting time

The method reported by $\mathrm{Bi}$ et al.16, was followed to measure tablet wetting time. A piece of tissue paper $(12 \mathrm{~cm} \times 10.75$ $\mathrm{cm}$ ) folded twice was placed in a small petridish (Internal diameter $=6.5 \mathrm{~cm}$ ) containing $6 \mathrm{~mL}$ of Sorenson's buffer $\mathrm{pH} 6.8$ having small volume of dye orange red. A tablet was put on the paper, and the time for complete wetting was measured. Test was conducted on three tablets and an average and standard deviation was calculated.

\section{Percent friability}

It is measured of mechanical strength of tablets. Roche friabilator (FB II, Electrolab, Mumbai) was used to determine the friability by following procedure. A preweighed tablet was placed in the fribaiator. Fribaiator consists of a plastic-chamber that revolves at $25 \mathrm{rpm}$, dropping those tablets at a distance of
6 inches with each revolution. The tablets were rotated in the friabalator for at least $4 \mathrm{~min}$. At the end of test tablets were dusted and reweighed, the loss in the weight of tablet is the measure of friability and is expressed in percentage as:

Friability $(\%)=($ Loss in weight / Initial weight $) \times 100$

\section{In vitro disintegration time}

The test was carried out on 6 tablets using the apparatus (DIA 32, Ketan Dial, Mumbai) specified in I.P. 1996, distilled water at $37^{\circ} \mathrm{C} \pm 2^{\circ} \mathrm{C}$ was used as a disintegration media and the time taken for complete disintegration of the tablet with no palpable mass remaining in the apparatus was measured. One-way analysis of variance (ANOVA) followed by Tukey multi-comparison test was used at a confidence to investigate differences among the studied groups of samples. ${ }^{17,18}$ 
In vitro drug release studies

In vitro drug release studies were carried out by using USP XXIII Dissolution Apparatus II (Disso 2000, Lablndia, Mumbai) (Paddle type) at $50 \mathrm{rpm}$. The drug release profile was studied in $500 \mathrm{~mL}$ of $\mathrm{pH} 6.8$ phosphate buffer by maintaining at $37 \pm 0.5^{\circ} \mathrm{C}$. Aliquots $(5 \mathrm{~mL})$ of dissolution medium were withdrawn at specific time intervals, filtered and the amount of drug released was determined spectrophotometrically (2101, Systronics, Ahmedabad). Three trials for each batch were performed and average percentage drug release with standard deviation was calculated and recorded.

\section{RESULTS}

Precompression characteristics of different batches of powder blends

For each designed formulation, blend of drug and excipients was prepared and evaluated for micromeritic properties as shown in Table 2. Angle of repose was $8.8 \pm 0.637$ to $16.7 \pm 0.921$, bulk density ranged $0.55 \pm 0.031$ to $0.82 \pm 0.072$, tapped density was in range $0.62 \pm 0.072$ to $0.98 \pm 0.12$. Carr's Compressibility Index for different formulations ranged between $5.88 \pm 0.39$ to $21.33 \pm 0.92$, Hausner's ratio ranged from $1.066 \pm 0.009$ to $1.27 \pm 0.08$.

\section{Evaluation of oral disintegrating tablets}

Hardness of the tablets was in the range $3.8 \pm 0.22$ to $4.7 \pm 0.11$ $\mathrm{kg}$, weight variation and friability test results were found within acceptable limits (Table 3 ).

\section{Disintegration time}

All the batches showed good disintegration time less than a min which qualifies them as ODTs. ODTs of batch F3 showed the lowest disintegration time of $19.28 \pm 3.11 \mathrm{~s}$. Equal amounts of both disintegrants (SSG and CCS) in this batch gave best results and tablets disintegrated in shortest time. One-way ANOVA followed by Tukey multi-comparison test $(p<0.05)$ showed significant difference in disintegration time of F3 formulation when compared to F1, F2, F4, F5, F16 and F17 formulations. When we used SSG or CCS as a single superdisntegrant in formulation F16 and F17 tablets disintegrated relatively slower, disintegration time was $28.37 \pm 2.26 \mathrm{~s}$ and $33.57 \pm 2.29 \mathrm{~s}$ respectively. In ODTs prepared with SSG+CCS, combination of disintegrants is proved as beneficial in reducing the disintegration time.

When SSG and Indion 414 were used as disintegrants in combination (Batch F6-F10), disintegration time increased when one of the disintegrant is at lowest concentration and the other at highest concentration (Table 3). One-way ANOVA followed by Tukey multi-comparison test $(p<0.05)$ showed significant difference in disintegration time of $\mathrm{F} 6$ formulation when compared to F7, F8, F9, F10, F17 and F19 formulations. When disintegration time of batches F6-10 was compared to Batch F17 and F19, it was observed that combination was beneficial in reducing the disintegration time of tablets.

In combination of CCS and Indion 414 (Batch F11-F15), disintegration time reduces with increasing the amount of CCS and corresponding decrease in the amount of Indion 414, which indicate a more prominent role of Indion 414 as disintegrant. One-way ANOVA followed by Tukey multi-comparison test ( $p<0.05$ ) showed significant difference in disintegration time of F11 formulation when compared to F12, F13, F14, F15, F17 and F18 formulations. All the tablets from batches from F10-F15 disintegrated in more than 30s time. When disintegration time of batches F11-15 were compared to Batch F17 and F18, it was observed that this combination was found not beneficial in reducing the disintegration time of tablets because disintegration time were longer than the disintegration time for batches F17 and F18. So, this combination of superdisintegrant failed to get any significant increase in disintegration time.

On the basis of disintegration time for batches F1-15, combination SSG+CCS in formulation F3 was best among other combinations studied on the basis on disintegration test.

\section{Friability}

Friability for batches F1-F19 was found within the acceptable limits. Batch F20 prepared with F-melt was greater than $1 \%$

\begin{tabular}{|c|c|c|c|c|c|}
\hline Batch & $\begin{array}{l}\text { Bulk } \\
\text { density } \\
\left(\mathrm{g} / \mathrm{cm}^{3}\right)\end{array}$ & $\begin{array}{l}\text { Tapped } \\
\text { density } \\
\left(\mathrm{g} / \mathrm{cm}^{3}\right)\end{array}$ & $\begin{array}{l}\text { Angle of } \\
\text { repose }\left({ }^{\circ}\right)\end{array}$ & Carr's index & $\begin{array}{l}\text { Hausner } \\
\text { ratio }\end{array}$ \\
\hline$=1$ & $0.55 \pm 0.03$ & $0.62 \pm 0.07$ & $11.32 \pm 0.12$ & $11.29 \pm 0.51$ & $1.13 \pm 0.05$ \\
\hline $\mathrm{F} 2$ & $0.66 \pm 0.08$ & $0.71 \pm 0.02$ & $9.68 \pm 0.32$ & $7.04 \pm 0.44$ & $1.08 \pm 0.01$ \\
\hline F3 & $0.67 \pm 0.04$ & $0.72 \pm 0.03$ & $10.20 \pm 0.11$ & $6.94 \pm 0.39$ & $1.07 \pm 0.00$ \\
\hline F4 & $0.65 \pm 0.05$ & $0.73 \pm 0.02$ & $12.80 \pm 0.43$ & $10.95 \pm 0.76$ & $1.12 \pm 0.01$ \\
\hline F5 & $0.64 \pm 0.04$ & $0.72 \pm 0.04$ & $8.80 \pm 0.64$ & $11.11 \pm 0.37$ & $1.16 \pm 0.06$ \\
\hline F6 & $0.59 \pm 0.03$ & $0.75 \pm 0.04$ & $13.20 \pm 0.76$ & $21.33 \pm 0.92$ & $1.27 \pm 0.08$ \\
\hline $\mathrm{F} 7$ & $0.62 \pm 0.07$ & $0.74 \pm 0.02$ & $14.60 \pm 0.57$ & $16.21 \pm 0.83$ & $1.19 \pm 0.01$ \\
\hline F8 & $0.69 \pm 0.07$ & $0.72 \pm 0.09$ & $11.10 \pm 0.32$ & $4.16 \pm 0.17$ & $1.04 \pm 0.05$ \\
\hline F9 & $0.66 \pm 0.04$ & $0.73 \pm 0.07$ & $12.20 \pm 0.43$ & $9.68 \pm 0.21$ & $1.11 \pm 0.06$ \\
\hline F10 & $0.68 \pm 0.05$ & $0.74 \pm 0.06$ & $16.70 \pm 0.92$ & $8.10 \pm 0.47$ & $1.08 \pm 0.02$ \\
\hline $\mathrm{F} 11$ & $0.66 \pm 0.06$ & $0.73 \pm 0.07$ & $15.80 \pm 0.76$ & $9.58 \pm 0.66$ & $1.10 \pm 0.01$ \\
\hline $\mathrm{F} 12$ & $0.63 \pm 0.01$ & $0.74 \pm 0.06$ & $14.10 \pm 0.44$ & $14.86 \pm 0.36$ & $1.17 \pm 0.01$ \\
\hline $\mathrm{F} 13$ & $0.69 \pm 0.03$ & $0.75 \pm 0.05$ & $9.92 \pm 0.66$ & $8.01 \pm 0.27$ & $1.08 \pm 0.03$ \\
\hline F14 & $0.64 \pm 0.03$ & $0.69 \pm 0.02$ & $13.24 \pm 0.19$ & $7.24 \pm 0.31$ & $1.08 \pm 0.01$ \\
\hline F15 & $0.67 \pm 0.08$ & $0.72 \pm 0.07$ & $11.90 \pm 0.22$ & $6.94 \pm 0.83$ & $1.09 \pm 0.01$ \\
\hline F16 & $0.63 \pm 0.02$ & $0.67 \pm 0.04$ & $12.70 \pm 0.12$ & $5.97 \pm 0.36$ & $1.07 \pm 0.01$ \\
\hline $\mathrm{F} 17$ & $0.59 \pm 0.01$ & $0.66 \pm 0.03$ & $11.30 \pm 0.42$ & $10.61 \pm 0.59$ & $1.12 \pm 0.03$ \\
\hline F18 & $0.64 \pm 0.03$ & $0.68 \pm 0.05$ & $11.90 \pm 0.24$ & $5.88 \pm 0.39$ & $1.07 \pm 0.02$ \\
\hline F19 & $0.61 \pm 0.04$ & $0.69 \pm 0.04$ & $12.30 \pm 0.29$ & $11.59 \pm 0.18$ & $1.13 \pm 0.05$ \\
\hline $\mathrm{F} 20$ & $0.82 \pm 0.07$ & $0.98 \pm 0.1$ & $14.40 \pm 0.17$ & $16.32 \pm 0.17$ & $1.20 \pm 0.10$ \\
\hline
\end{tabular}

All values are mean \pm standard deviation of three determinations 
which might be due to lower compressibility of the co-processed excipient. Friability of $0.92 \%$ was observed in batch $\mathrm{F} 3$, which gave maximum disintegration time. A minimum friability of $0.39 \%$ was achieved in batch $\mathrm{F} 9$.

\section{Drug release studies}

Drug release profiles of different ODTs are provided as Figure $1,2,3,4,5$. Fastest drug release of $102.2 \pm 2.11 \%$ in 20 min was achieved for salbutamol sulphate ODTs of Batch F3, among batches F1-15. Batch F3 utilized disintegrants SSG and CCS, which might have showed additive/synergistic action. ODTs of Batch F20, prepared with marketed ODT excipient blend F-melt, release $98.50 \pm 2.4 \%$ drug in 15 min. Batch F3 was the best formulation among prepared ODT blends which gave drug release which may be related to its best shortest disintegration time. Minimum drug release of $91.47 \pm 2.59 \%$ in 30 min was achieved for ODTs of Batch F18, which contained a single disintegrant Indion 414. While, batch F16 and F17, which contained individual superdisintegrant SSG and CCS respectively, showed relatively faster drug release of $94.57 \pm 1.39 \%$ in $25 \mathrm{~min}$ and $93.19 \pm 2.12 \%$ in $30 \mathrm{~min}$.

\section{DISCUSSION}

Angle of repose was less than $25^{\circ}$ for all powder blends which indicated excellent flow properties. On the other hand, powder blends for F1-F5, F7-F19 formulations scored either good or excellent on scale of flowability based on Hauser's ratio and compressibility index as per USP. ${ }^{19}$ Powder blends for F7 and F20 formulations were fair to flow. However, powder blend for

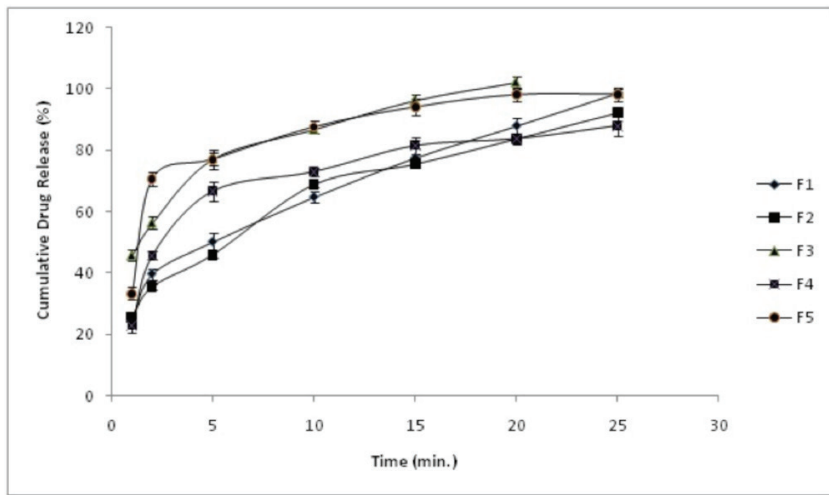

Figure 1. Drug release profile of salbutamol sulphate oral disintegrating tablets for batches F1-F5 ( $n=3$, mean \pm standard deviation is reported)

\section{Table 3. Characterization of prepared salbutamol sulphate ODTs}

\begin{tabular}{|c|c|c|c|c|c|c|c|}
\hline Batch & $\begin{array}{l}\text { Weight } \\
\text { variation (\%) } \\
(n=20)\end{array}$ & $\begin{array}{l}\text { Diameter }(\mathrm{mm}) \\
(\mathrm{n}=3)\end{array}$ & Thickness $(\mathrm{mm})(\mathrm{n}=3)$ & $\begin{array}{l}\text { Hardness }\left(\mathrm{kg} / \mathrm{cm}^{2}\right) \\
(\mathrm{n}=3)\end{array}$ & $\begin{array}{l}\text { Wetting time }(s) \\
(n=3)\end{array}$ & $\begin{array}{l}\text { Friability (\%) } \\
(n=20)\end{array}$ & $\begin{array}{l}\text { Disintegration } \\
(s)(n=6)\end{array}$ \\
\hline $\mathrm{F} 2$ & 2.24 & $8.19 \pm 0.15$ & $3.33 \pm 0.07$ & $4.10 \pm 0.12$ & $58.33 \pm 6.11$ & 0.64 & $25.65 \pm 2.28$ \\
\hline F3 & 3.36 & $8.20 \pm 0.00$ & $3.30 \pm 0.00$ & $3.90 \pm 0.67$ & $52.32 \pm 4.12$ & 0.92 & $19.28 \pm 3.11$ \\
\hline $\mathrm{F} 5$ & 4.22 & $8.19 \pm 0.15$ & $3.30 \pm 0.00$ & $4.10 \pm 0.42$ & $58.82 \pm 5.60$ & 0.48 & $26.92 \pm 3.62$ \\
\hline F6 & 2.91 & $8.20 \pm 0.00$ & $3.30 \pm 0.00$ & $4.10 \pm 0.42$ & $58.13 \pm 3.26$ & 0.77 & $27.67 \pm 1.89$ \\
\hline F7 & 3.29 & $8.20 \pm 0.00$ & $3.31 \pm 0.06$ & $3.90 \pm 0.55$ & $63.66 \pm 4.89$ & 0.81 & $28.82 \pm 2.88$ \\
\hline F8 & 5.12 & $8.20 \pm 0.00$ & $3.10 \pm 0.17$ & $4.00 \pm 0.37$ & $66.24 \pm 5.12$ & 0.96 & $32.39 \pm 3.28$ \\
\hline $\mathrm{F} 11$ & 4.17 & $8.20 \pm 0.00$ & $3.36 \pm 0.04$ & $4.70 \pm 0.11$ & $57.33 \pm 5.26$ & 0.67 & $32.38 \pm 1.77$ \\
\hline $\mathrm{F} 12$ & 1.12 & $8.20 \pm 0.00$ & $3.30 \pm 0.00$ & $3.90 \pm 0.82$ & $63.28 \pm 6.29$ & 0.84 & $33.44 \pm 2.29$ \\
\hline $\mathrm{F} 13$ & 3.72 & $8.20 \pm 0.00$ & $3.20 \pm 0.00$ & $4.20 \pm 0.29$ & $67.58 \pm 3.72$ & 0.58 & $34.71 \pm 1.49$ \\
\hline F14 & 4.49 & $8.20 \pm 0.00$ & $3.46 \pm 0.20$ & $4.10 \pm 0.31$ & $65.72 \pm 4.11$ & 0.69 & $34.82 \pm 2.81$ \\
\hline F15 & 3.12 & $8.20 \pm 0.00$ & $3.34 \pm 0.07$ & $4.20 \pm 0.67$ & $61.49 \pm 3.81$ & 0.88 & $35.10 \pm 3.71$ \\
\hline F16 & 2.29 & $8.23 \pm 0.04$ & $3.40 \pm 0.07$ & $4.10 \pm 0.17$ & $62.42 \pm 2.98$ & 0.52 & $28.37 \pm 2.26$ \\
\hline $\mathrm{F} 17$ & 3.46 & $8.19 \pm 0.15$ & $3.34 \pm 0.06$ & $3.90 \pm 0.21$ & $64.57 \pm 2.19$ & 0.87 & $33.57 \pm 2.29$ \\
\hline
\end{tabular}

ODTs: Oral disintegrating tablets, All values are mean \pm standard deviations, Number of tablets used for testing has been reproted in each coloum heading 
formulation F6 was passable All powder blends were flowable and posed no difficulty in tabletting by direct compression. Hardness and friability of all the batches were found within the acceptable range. Tablets from all the batches disintegrated quickly in less than 40 s and thus qualifies the criterion for ODTs.

In the combination A of superdisintegrants (batch F1-F5), SSG and CCS were used as disintegrants. As we increased the amount of SSG in combination and moved towards the batches $F 2, F 3, F 4$, and F5, at the point where both superdisintegrants were in equal amount in formulation i.e. batch F3, it took lowest time $(19.28 \pm 3.11 \mathrm{~s})$ to disintegrate and showed fastest

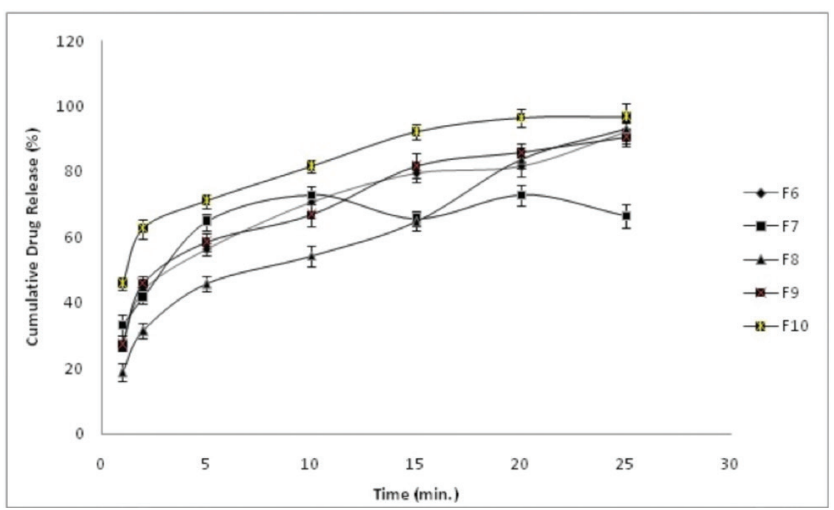

Figure 2. Drug release profile of salbutamol sulphate oral disintegrating tablets for batches F6-F10 ( $n=3$, mean \pm standard deviation is reported)

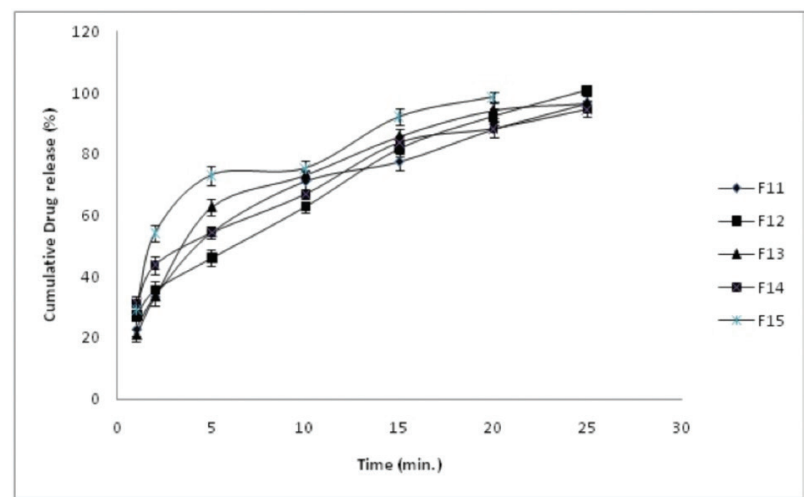

Figure 3. Drug release profile of salbutamol sulphate oral disintegrating tablets for batches F10-F15 ( $n=3$, mean \pm standard deviation is reported)

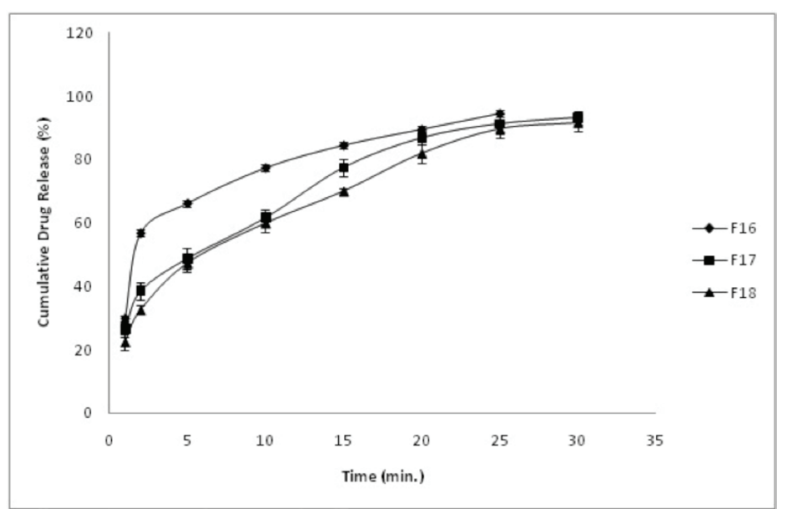

Figure 4. Drug release profile of salbutamol sulphate oral disintegrating tablets for batches F16-F18 ( $n=3$, mean \pm standard deviation is reported) drug release $(102.2 \pm 2.11 \%$ in $20 \mathrm{~min})$ among these five batches (F1-F5). Total concentration of $12.5 \%$ disintegrant was used in preparing ODTs. F4 contained $9.375 \%$ and $11.25 \%$ of SSG, which is very much higher than its optimum concentration for disintegrant effect. At $8 \%$ or higher concentration it swells to a gel which increases disintegration time of ODTs. ${ }^{20}$ Hence, it is anticipated that the gelling effect due to high concentration of SSG acts adversely to reduces the disintegration time of ODTs of batches F4 and F5. In one similar study, disintegrant blend of CCS and SSG in 1:1 ratio was used to prepare ODTs of certirizine hydrochloride $(\mathrm{HCl})^{21}$ and Ondansetron $\mathrm{HCl}^{22}$ Quick water uptake and good swelling ability of CCS and SSG is ascribed to the carboxylic moieties in their structure which upon hydration results in gelation. ${ }^{23}$ Particle size and amorphous content in the disintegrant may also affect easy water accessibility.

In the combination B (batch F6-F10), SSG and Indion 414 were used as disintegants. Among these batches (F6-F10), the best formulation F10 with $90 \%$ of SSG and $10 \%$ of Indion 414 , disintegrated in $22.6 \pm 1.62$ s and $96.73 \pm 4.12 \%$ drug release was achieved in $25 \mathrm{~min}$. As the concentration of Indion 414 increased with simultaneous decrease in SSG, the formulations took more time to disintegrate probably due to insoluble nature of Indion 414 particles. ${ }^{24}$

In the combination C (batch F11-F15), CCS and Indion 414 were used, formulation $\mathrm{F} 12$ was the best formulation in combination $C$ which showed a complete disintegration in $33.44 \pm 2.29 \mathrm{~s}$ and $100.7 \pm 1.77 \%$ in 25 min. An optimum swelling action contributed by Indion 414 and wicking action of CCS was anticipated when these are combined in 3:1 ratio.

ODT batches F16, F17, and F18 were prepared with single disintegrant SSG, CCS, and Indion 414, respectively. As a single superdisintegrant SSG gave best results of disintegration time $28.37 \pm 2.26 \mathrm{~s}$ and $94.57 \pm 1.39 \%$ drug release in $25 \mathrm{~min}$. Furthermore, drug release at initial time points, especially at $2 \mathrm{~min}$, was significantly higher in case of F16 formulation containing SSG as disintegrant. However, no significant difference in disintegration time was observed for CCS and Indion 414.

Among all ODT batches (F1-F18), F3 was the best formulation with fastest disintegration time of $19.28 \pm 3.11 \mathrm{~s}$ and acceptable friability. Combination of disintegrants in ODT batch F3 was

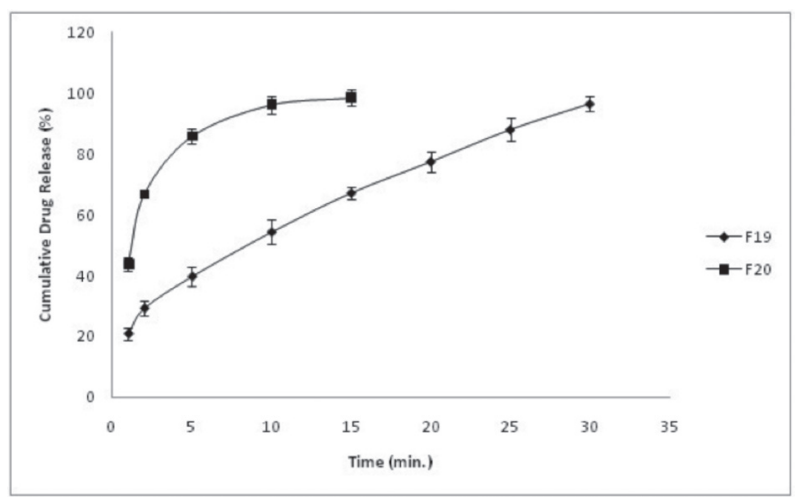

Figure 5. Drug release profile of salbutamol sulphate oral disintegrating tablets for batches F19-F20 ( $n=3$, mean \pm standard deviation is reported) 
more effective than formulation F19 prepared with marketed blend, Prosolv ODT, which disintegrated in $32.13 \pm 2.11 \mathrm{~s}$. Highest cumulative drug release (\%) and faster disintegration of salbutamol sulphate ODTs in batch F3 was probably due to the additive/synergistic mechanisms of disintegrant action, i.e. high swelling index of SSG (7-12 folds) in three dimensions, along with swelling and wicking action of CCS. Increasing the amount of any one of the superdisintegrant and reducing the other, we observed an increase in disintegration time of tablet.

ODTs of batch F19, prepared by with marketed blend ProsolvODT, disintegrated completely in $32.13 \pm 2.11 \mathrm{~s}$ and $96.55 \pm 2.33 \%$ drug release was achieved in $30 \mathrm{~min}$. Friability was $0.71 \%$ and wetting time was $55.66 \pm 3.21 \mathrm{~s}$. Weight variation of $4.71 \%$ and hardness of $3.9 \pm 0.1 \mathrm{~kg}$ was achieved. Prosolv ODT is the unique combination of soluble and insoluble ingredients manufactured using JRS Pharma's (http://www.jrspharma.com/) coprocessing technology. Prosolv contains MCC, colloidal silicon dioxide, mannitol, fructose, and crospovidone. ${ }^{25,26}$ Prosolv $^{\circledR}$ ODT is an ODT excipient matrix which allows a rapid formulation development and quality tablet manufacture.

ODT batch F20 prepared with F-melt marketed blend gave fastest disintegration of $15.5 \pm 2.42 \mathrm{~s}$, and dissolution of $98.50 \pm 2.49 \%$ after $15 \mathrm{~min}$ and a fastest wetting time $44.33 \pm 2.52 \mathrm{~s}$. However, the friability was greater than $1 \%$. Furthermore, weigh variation was maximum (6.68\%) and hardness was towards lower side $3.9 \pm 0.058 \mathrm{~kg}$. Low hardness and friabile ODTs prepared with F-melt swelled and disintegrated quickly resulting in faster dissolution of the drug. F-melt was difficult to handle due to its hygroscopic nature. F-melt (http://www.f-melt.com/) is a spray-dried excipient used in ODTs that contain five different pharmaceutical ingredients consisting of carbohydrates (mannitol, xylitol and microcrystalline cellulose), disintegrant (crospovidone), and inorganic excipients (magnesium aluminosilicate, dibasic calcium phosphate anhydrous). ${ }^{25}$ ODTs can be easily manufactured through direct compression only by adding $\mathrm{F}$-melt to the active ingredient and lubricant. F-melt type $\mathrm{C}$ is recommended for faster disintegration needs in both pharmaceutical and nutraceutical formulations. ${ }^{27} \mathrm{~F}$-melt contains mannitol, xylitol, MCC, crospovidone, dibasic calcium phosphate anhydrous and magnesium aluminosilicate. ${ }^{25} \mathrm{~F}$-melt was hygroscopic at humidity conditions higher than $75 \%$ relative humidity. We also observed that F-melt is not suitable esthetically at higher humidity conditions. At accelerated stability conditions for 6 months, benzocaine ODTs diameter was increased by $2 \mathrm{~mm}$ due to swelling of tablet by moisture uptake. ${ }^{25}$ F-melt contains crospovidone which can swells upon contact with water or moisture. Carr's Compressiblity Index for F20 was $16.32 \pm 0.172$ and $1.195 \pm 0.098$ which was probably due to hygroscopic nature of F-melt.

\section{CONCLUSION}

Salutamol sulphate ODTs of batch F3 were best ODTs prepared with combination of superdisintegrants. The present work revealed that binary combination of disintegrants is more effective than individual use disintegrants. Among all combinations of disintegrants, SSG and CCS (1:1 ratio) gave best results for both disintegration and drug release. ODTs of batch F3 disintegrate a little slower than ODT prepared with F-Melt (batch F20) but faster than ODTs containing Prosolv ODT (batch 19). F-Melt is a hygroscopic blend and need special handling, storage, and processing care. However, composition of $\mathrm{F} 3$ does not pose any problem of hygroscopicity. This aspect of F3 makes it a suitable alternative to a marketed blend like F-Melt or Prosolv ODT.

\section{ACKNOWLEDGEMENTS}

Authors are thankful to JRS Pharma, Germany for CCS and Prosolv ODT; Signet Chem. Corporation, Mumbai for MCC; Ion Exchange (India) Ltd, Ahmedabad for Indion 414; Service Techniques Et Laboratories, Lestrem, France for mannitol; and Fuji Chemical Industry Co. Ltd., Tokyo for F-melt type C ex gratis samples.

Conflict of Interest: No conflict of interest was declared by the authors.

\section{REFERENCES}

1. Mehta K, Garala K, Basu B, Bhalodia R, Joshi B, Charyulu NR. An Emerging trend in oral drug delivery technology: rapid disintegrating tablets. J Pharm Sci Tech. 2010;2:318-329.

2. Smith WA, Dellarosa DM. Approaches to treating dysphagia in patients with brain injury. Amer J Occ Ther. 1994;48:235-239.

3. Shukla D, Chakraborty S, Singh S, Mishra B. Mouth dissolving tablets: An overview of formulation technology. Sci Pharm. 2009;77:309-326.

4. FDA C. Guidence for industry, orally disintegrating tablets. Available at http:// www.fda.gov/cder/guidance/index.htm Accesssed On 14th March 2014.

5. Bikshapathi D, Saikrishna K, Uppuluru AK, Sabitha G, Saikumar B. Fast dissolving tablets: an update. Int Res J Pharm. 2011;2:45-53.

6. Tripathi KD. Essentials of Medical Pharmacology. $6^{\text {th }}$ ed. New Delhi: Jaypee Prakashan; 2008.

7. Patni SD, Gondkar S, Darekar A, Sharma Y, Saudagar R. Comparative evaluation of natural and synthetic superdisintegrants for fast dissolving tablet. J Drug Deliv Ther. 2013;3:22-30.

8. Prasanth V, Sarkar S, Tribedi S, Mathappan R, Mathew S. Formulation and evaluation of orodispersible tablets of salbutamol sulphate. Research and Reviews: J Pharm Pharmaceut Sci. Available at http://www.rroij.com/ open-access/formulation-and-evaluation-of-orodispersible-tablets-ofsalbutamol-sulphate.php?aid=35009 Accesssed On 30 May 2016.

9. Sharma D, Singh G, Kumar D, Singh M. Formulation development and evaluation of fast disintegrating tablets of salbutamol sulphate, cetirizine hydrochloride in combined pharmaceutical dosage form: A new era in novel drug delivery for pediatrics and geriatrics. J Drug Deliv. 2015;2015:640529.

10. Dineshmohan S, Vanitha K, Ramesh A, Srikanth G, Akila S. Formulation and evaluation of salbutamol sulphate fast dissolving tablet. Int $\mathrm{J}$ Res Pharmaceut Biomed Sci. 2010;1:105-108.

11. Nanjwade BK, Udhani R, Popat J, Nanjwade VK, Thakare SA. Development and characterization salbutamol sulphate mouth disintegrating tablet. $J$ Chem Eng Process Technol. 2012;2011. 
12. Seth N, Goswami J, Sharma S, Gupta G. Orodispersable tablets of salbutamol suphate using combinational approaches for disintegration: For effective management of asthma. Internet J Pulm Med. 2008;11:1-6.

13. Bhise S, Chaulang G, Patel P, Patel B, Bhosale A, Hardikar S. Superdisintegrants as solubilizing agents. Res $\mathrm{J}$ Pharm and Tech. 2009;2:387-391.

14. Patil C, Das S. Effect of various superdisintegrants on the drug release profile and disintegration time of Lamotrigine orally disintegrating tablets. Afr J Pharm Pharmacol. 2011;5:76-82.

15. Amin P, Prabhu N, Wadhwani A. Indion 414 as superdisintegrant in formulation of mouth dissolve tablets. Indian Journal of Pharmaceutical Sciences. 2006;68:117-119.

16. Bi Y, Sunada H, Yonezawa Y, Danjo K, Otsuka A, lida K. Preparation and evaluation of a compressed tablet rapidly disintegrating in the oral cavity. Chem Pharm Bull. 1996;44:2121-2127.

17. Spaniol Br, Bica VC, Ruppenthal LR, Volpato MR, Petrovick PR. Compressional behavior of a mixture of granules containing high load of Phyllanthus niruri spray-dried extract and granules of adjuvants: comparison between eccentric and rotary tablet machines. AAPS Pharm Sci Tech. 2009;10:1013-1023.

18. Scheuerle RL, Gerrard SE, Kendall RA, Tuleu C, Slater NK, Mahbubani KT. Characterising the disintegration properties of tablets in opaque media using texture analysis. Int J Pharm. 2015;486:136-143.

19. USP/NF24. General Chapter 〈1174〉 Powder Flow. Rockville, MD: US Pharmacopeial Convention; 2006.
20. Sharma D. Formulation development and evaluation of fast disintegrating tablets of salbutamol sulphate for respiratory disorders. ISRN Pharmaceutics 2013; Article ID 674507:http://dx.doi. org/10.1155/2013/674507.

21. Basu B, Bagadiya A, Makwana S, Kapadiya M. Design and evaluation of sublimed orodispersible tablets of Cetrizine $\mathrm{HCl}$ using superdisintegrant blends by direct compression. Int J Pharm Pharm Sci. 2011;3:435-441.

22. Gosai AR, Patil SB, Sawant KK. Formulation and evaluation of orodispersible tablets of ondansetron hydrochloride by direct compression using superdisintegrants. Int J Pharm Sci Nanotechnol. 2008;26:106-111.

23. Rojas J, Guisao S, Ruge V. Functional assessment of four types of disintegrants and their effect on the spironolactone release properties. AAPS Pharm Sci Tech. 2012;13:1054-1062.

24. Indion 414. Product Data Sheet. Mumbai: Ion Exchange (India) Ltd.; 2008.

25. Kollmer M, Popescu C, Manda P, Zhou L, Gemeinhart R. Stability of benzocaine formulated in commercial oral disintegrating tablet platforms. AAPS Pharm Sci Tech. 2013;14:1333-1340.

26. Prosolv ${ }^{\circledast}$ ODT G2: Orally Disintegrating Tablet Excipient Matrix. Available at http://www.jrspharma.com/pharma_en/products-services/ excipients/hfe/prosolv-odt-g2.php Accesssed On 31 May 2016.

27. Krupa A, Jachowicz R, Pedzich Z, Wodnicka K. The influence of the API properties on the ODTs manufacturing from co-processed excipient systems. AAPS Pharm Sci Tech. 2012;13:1120-1129. 